\title{
Individual taste preferences and excessive body weight of children
}

\author{
Grzegorz Sobek', Artur Mazur² \\ 'Institute of Nursing and Health Sciences, Faculty of Medicine, University of Rzeszow, Rzeszow, Poland \\ 2Department of Paediatrics, Paediatric Endocrinology, and Diabetes, Faculty of Medicine, University of Rzeszow, \\ Rzeszow, Poland
}

\section{ABSTRACT}

Eating habits and customs are formed at an early age, and they play a special role in the prevention of overweight and obesity. Accepting something as food is largely determined by food preferences. Forming food and taste preferences is particularly intensive in early childhood. Sensory vulnerability of taste recognition apparatus is a personal trait that can influence the perception of food products and everyday food choices. A preference for sweet or fat taste may contribute to an increase in eating food of high energy density that can run overweight risk. Yet, the mechanism that gives people various taste sensitivity, various food preferences, and react differently to eaten food, remains unclear. Undoubtedly taste preferences are one of many factors that determine overweight and obesity among children and adolescents. However, a reverse relationship may be suggested here, i.e. taste preferences are a result of obesity.

\section{KEY WORDS:}

children, taste perception, taste preferences, overweight, obesity.

\section{INTRODUCTION}

Overweight is a serious health problem. In Poland, like in many other countries, a considerable increase in the number of children and adolescents affected by the problem has been indicated. In the last 30 years overweight among boys aged between 11 and 15 years has increased three-fold and among girls even 10 -fold $[1,2]$. There is more and more evidence proving the theory that children who are overweight before reaching puberty may also be overweight in their future life, also as adults $[3,4]$. Environmental variables that are to a large extent modifiable play a crucial role in overweight and obesity prevention. Eating habits and food preferences are among those environmental variables that considerably increase the risk of obesity [5]. The choice of food made by children greatly depends on their taste preferences. Taste preference forms in early childhood. In general, children prefer products of a sweet milk-like taste and rich in fat, which are characterised by high energy density. In their later life, food perception is also determined by food product intake (eating customs and culture). There is evidence proving that eating habits and patterns are acquired in early childhood and cultivated into adulthood or even old age [6]. An improperly composed diet in terms of quality and quantity, parents' unhealthy eating habits, missing family meals, and lack of physical exercise or sleep are basic factors that are positively correlated with obesity. Family eating habits play a pivotal role in preventing overweight and obesity. Parents' knowledge and food selection preferences are connected with their children's particular eating behaviour [7].

\section{ADDRESS FOR CORRESPONDENCE:}

Grzegorz Sobek, Institute of Nursing and Health Sciences, Faculty of Medicine, University of Rzeszow,

2a Kopisto Ave, 35-959 Rzeszow, Poland, e-mail: g.sobek@wp.pl 


\section{THE TERMS TASTE AND TASTE PREFERENCES}

"Taste" is a term that is closely associated with nutrition. It is the subjective reaction caused by sensory stimuli felt by means of the sense of taste, which specialises in detecting and recognition of tastes such as sweet, sour, bitter, salty, umami, and fat. As a result of combining identified taste stimuli with olfactory and visual ones, complex eating habits are formed. Taste cooperates with the central motivation systems and indirectly takes part in the digestion process influencing production of the digestive enzymes. Taste recognition is highly important for the human body because it a symbol of satisfying hunger and the sense of checking food quality [8]. Sensing its taste significantly influences the choice of eaten food and the type of followed diet. It also contributes to consumption of the food and dishes that we accept, but it can also save humans from eating substances that are hazardous to health, e.g. toxic, rotten, or unripe [9]. The term "preferences" refers to the theory of making a decision, when an agent chooses one of several available options [10]. Actually, there may be many reasons that make humans decide on a particular food option, but the most frequent interpretation of the term "preferences" refers to "liking" or "disliking". Taste preferences may be defined as making choices based on one's own, subjective, hedonic ("pleasant", "unpleasant") experiences. Taking into consideration the close relation between taste preferences and food selection, the term "food preferences" is used to indicate liking one type of food more than another, or even hating it. It should be highlighted that taste preferences are one of the possible factors that determine eating a particular food product. It is possible that an adult choosing between coffee and orange juice, both of which they like very much, will choose coffee due to its "stimulating" effect. When choosing food, children are guided by its taste, whereas other motivating factors such as being healthy play a minor role [11].

\section{REASONS FOR CHANGE AND DIFFERENCES IN TASTE PREFERENCES}

Developing taste and food preferences is particularly intensive in early childhood. However, chemosensory perception differs in different people due to many factors, and it changes when reaching puberty or maturity [12]. According to Gawęcki, individual food preferences are determined by "patterns acquired in childhood, cultural and social environment, personality traits, early consuming experiences, fashion, advertising, food knowledge" [13]. Inborn taste preferences observed at prenatal stage and in the first months of life are present in childhood and gradually disappear in the process of growth. Children, when compared to adults, are more sensitive to bitter taste. A difference in taste preferences between children and adults was also detected regarding other tastes. Children prefer products of sweeter taste, with higher content of salt, even bitter [14-17]. The theory of the evolutionary adaptation to different conditions of "food" environment is adopted. Wider acceptance of the greater taste concentration allows higher sensitivity to a wide range of tastes and products that are introduced into infant's diet.

The reasons for the difference in taste sensitivity are complex and caused by many genetic, physiological, and environmental factors. The factors that influence the sensory perception can also be determined by age, gender, the level of nourishment, illnesses, and treatment [18].

\section{GENETIC VARIABLES}

Inborn predispositions observed in children are closely related to genetic diversity emerged from gene polymorphism. Genetic research has shown genetically determined, individual differences in the perception of bitter taste regarding substances such as quinine, phenylthiocarbamide (PTC), and 6-n-propylthiotiouracil (PROP). A researched group particularly sensitive to PROP/PTC were called super-testers. A great deal of research carried out on children and adults proved that high taste sensitivity is connected with the number of tongue taste buds. Higher sensitivity applies to the basis tastes, especially to sweet taste, the taste of chili pepper, and the feeling of "creamy taste" of oil emulsion [19]. 25\% of our population showed lower than average ability to recognise substances of sweet or bitter taste, and belong to a group of non-tasters, to whom bitter components containing phenylthiocarbamide are tasteless [20]. Bimodality to this component is caused by distinct genotypes of the TAS2R38 receptor [21]. It is believed that polymorphism of the TAS2R38 receptor represented by different sensitivity to a bitter taste is environmentally conditioned. Taste sensitivity associated with a particular genotype variation influences the feeling of satisfaction gained from eating and eating behaviour. It has been proven that weaker reaction to a bitter taste of propylthiouracil (PROP) is characteristic of people with alcohol problems and of children. People of high sensitivity to PROP avoid eating vegetables belonging to a Cruciferae group that have bitter aftertaste. They also like less sweet dishes and those of high fat content [22].

\section{SHAPING PREFERENCES BY TEACHING}

Genetic diversity explains only partially the differences in children's individual taste preferences. It is more difficult to justify changes in taste preferences that occur during childhood and puberty. When explaining these changes, one places emphasis on shaping preferences by the process of teaching. The stage of introducing a complementary diet represents the most important phase of teaching the preferences and bringing the appetite under control in a human's life. Infants discover sensory stimuli (texture, smell, taste) and food nutrition properties (energy density), which are a part of an adult's diet [23]. Previ- 
ous research suggests that too much exposure to the sweet taste may maintain and even strengthen a liking for food rich in sugar [24]. Children's preferences for products containing a lot of fat are associated with the energy produced by fat. It was observed that higher fat consumption at the age of two years was combined with lower body weight and leptin in adulthood [25]. The consequence of eating may be wellbeing and the feeling of fullness, or negatively associated nausea and vomiting [26, 27]. In the process of sensory learning these positive or negative experiences are combined with taste preferences of consumed food influencing one's liking or disliking it.

Higher consumption of sweet food can be associated with preferences for sweet taste and the mother's attitude and habits concerning cooking [28]. Adding sugar to an infant's food in the same proportion as to other family member' dishes is a frequent mistake. Due to long-term influence on children's health as well as developing proper eating habits and preferences, dieticians, doctors, and organisations dealing with children's nutrition recommend unsweetened complementary food and reduced consumption of simple sugars [29].

\section{ENVIRONMENTAL VARIABLES}

Parents play a pivotal role in developing taste preferences in children and adolescents. Their contribution in developing sensory experiences is not only limited to "giving an example" but also has a wider context. Parents can consciously or unconsciously control accessibility of food products and at the same time influence exposition to various tastes. Moreover, their decisions influence the child's social environment and indirectly contribute to developing his/her sensory preferences [30]. In the period of growth, parents can unconsciously influence their offspring's preferences by using some products as a reward for eating dishes that children do not like. Often enough, motivating children to eat vegetables by using a sweet desert as a reward creates an adverse effect, i.e. decreasing interest in eating this product in the long run. Actually, the proposed food is devalued and a negative signal about it is sent [31]. There is no doubt that children and adolescents are positively and negatively influenced, which is why their parents' habits and eating behaviour seem to be crucial in developing their offspring's taste preferences. It was stated that children following their peers and parents' example more willingly try and accept dishes that they did not tolerate previously [32]. The older children are, the more independent they become regarding their food choices. They become more influenced by their environment: school, peers, social organisations, good marketing [33].

\section{TASTE PREFERENCES AND OVERWEIGHT}

In recent years, essential consumption patterns have been changed due to the "fast pace of life" combined with aggressive marketing. Products of higher energy density, and higher content of sugar and fat, such as fast food, sweet breakfast cereals, sweets, snacks, and sweetened beverages have become more popular among children [34]. Previous research proved that liking or a strong preference for sweet taste is connected with higher consumption of food rich in sweet taste, sweet beverages, or preferring breakfast cereal with higher content of sugar [35]. According to Cox [36], the author of the latest literature review in this field, research carried out within the EU-wide research project IDEFICS (identification and prevention of dietary and lifestyle-induced health effects in children and infants) is of the highest methodological value. The research within the IDEFICS project conducted on a group of children from Europe aged from six to nine years proved that those who preferred sweet taste showed $50 \%$ higher probability of being overweight than the group that chose less sweet taste [37]. In this paper the relation between fat taste preferences and overweight has been also proved. Some articles found in the literature emphasise the concomitance of preferences for sweet taste with preferences for fat taste in the target group, which was suggested by Bartoshuk [38] and proven by Lanfer [37], who stated that the probability of overweight and obesity among girls increased if preferences for fat taste were accompanied by preferences for sweet taste.

Various people show different sensitivity to each of the tastes $[39,40]$. Gawęcki [41] proved that taste preferences are related to taste sensitivity. He observed that people of lower sensitivity to sweet taste liked drinking sweet tea more. The latest papers have also proven that people with lower sensory sensitivity prefer higher concentrations of particular tastes [42]. The consequence of individual differences in taste perception can result in disproportion in consumption of certain diet elements, especially sugar and fat, which can lead to higher calorific value in a diet. The research conducted with the use of samples containing various amount of glucose proved the relation between individual preferences for sweet taste and preferences for sweet beverages. The diet of people who liked sweeter products was characterised by a higher intake for energy and a higher consumption of carbohydrates (starch, fructose, glucose, sugars) [35]. The majority of research points to a positive relation between the acceptance for higher content of fat and BMI or body weight $[43,44]$. The hypothesis has often been formulated that overweight people are less sensitive to texture-taste stimuli when tasting fat products. That is why assessing fat content by these people involves more strenuous effort. At the same time, overweight people can be less sensitive to unpleasant sensory fat acids, which may cause their appetite not to become weakened in regard to some fat products or dishes [45]. Stewart and Keast [46] proved that oversensitivity to fat acids is correlated with lower consumption of energy from fats and lower BMI of the examined subjects. Available research is ambiguous with regard to the relation between 
taste sensitivity and being overweight or obese. The majority of literature deals with the level of sensory sensitivity comparing levels of sensitivity to various tastes on standardised aqueous solutions. Overberg et al. [47], in research carried out on people aged 6-18 years, highlighted significant differences in sensory sensitivity. They proved that overweight people identified falsely lower concentrations of salty, sweet, umami, and bitter tastes than the examined people of proper weight. But research carried out on a group of obese teenagers (average BMI = 39.5) when compared with the target group (average BMI $=21$ ) showed higher abilities of the overweight people to assess sweet and salty tastes [48].

Undoubtedly, many facts prove that taste preferences are correlated with sensory perception, food consumption, and weight. However, the mechanisms that make people of different taste sensitivity and taste preferences react differently to eaten food remains unclear. The majority of theories suggest that people of a lower sensitivity threshold to, e.g., sweet taste feel the same pleasure from relatively lower concentrations of stimuli, which is why they do not like food that is very sweet. People who are less sensitive to this taste, to experience the same pleasure, need a stronger stimulus, which is why they prefer sweeter products. This explains the discrepancy in consumption of certain products between sensitive and less sensitive people, but it does not explain entirely the level of consumption that exceeds energetic needs, as in the case of overweight people. Alternatively, it has been suggested that intensive stimuli, especially those that last for a longer period of time, may result in permanent raising of the threshold of sensitivity. The higher the concentration of the stimulus and longer exposure to it, the greater the changes become [49]. A diet rich in fat may lead to getting used to the certain level of concentration of the stimulus and the need to increase it to the desired quantity felt in the mouth [50-52]. This can result in an increase of quantity of consumed fat and gaining weight. In research by DiPatrizio [53], after four weeks on a low-calorie diet, both slim and overweight people showed higher sensitivity to fat acids than before following the diet. In the case of a high-fat diet the level of sensitivity of overweight and obese people did not change, which can lead to the conclusion that the people got used to the permanent high-fat diet.

\section{CONCLUSIONS}

Childhood is a crucial period in forming taste, preferences, and food habits as well as potential weight problems. In a world abounding in food rich in sugar and its derivates, sweetened beverages, and commercially prepared baby food [54], increased preferences for sweets may make children more vulnerable to overconsumption of these products [55]. Breast feeding and early exposure to a variety of products of various tastes have an influ- ence on later food preferences and habits [56]. The fact that sweet taste is the basic and the most desirable one present in food suggests that actions leading to weakening its preference may cause problems. Research has proven that taste preferences are one of many factors determining overweight and obesity among children and adolescents. However, there are doubts about whether there is a negative relation, i.e. taste preferences are a result of obesity. Probable metabolic dysfunctions connected with overweight may lead to changes in hormonal taste regulation processes and finally to changes in taste preferences. Moreover, parents of overweight children are often very restrictive in regard to eating food rich in sugar and fat, which may lead to the increase in preferences for sweet and fat tastes $[57,58]$. It seems that understanding the influence of taste preferences on food choices of children may become a crucial factor in treating overweight and obesity.

\section{DISCLOSURE}

The authors declare no conflict of interest.

\section{REFERENCES}

1. Chrzanowska M, Koziel S, Ulijaszek SJ. Changes in BMI and the prevalence of overweight and obesity in children and adolescents in Cracow, Poland, 1971-2000. Econ Hum Biol 2007; 5: 370-378.

2. Kovesby CP, Furth SL, Zoccali C. Obesity and kidney disease: Consequences of the epidemic. Blood Purif 2017; 43: 346-354.

3. Jones RE, Jewell J, Saksena R, et al. Overweight and Obesity in Children under 5 Years: Surveillance Opportunities and Challenges for the WHO European Region. Front Public Health 2017; 5: 58.

4. Nishtar S, Gluckman P, Amstrong T. Ending childhood obesity: a time for action. Lancet 2016; 387: 825-827.

5. Kolarzyk E, Janik A, Kwiatkowski J. Ocena ryzyka zespołu metabolicznego u dzieci z nadwagą i otyłością. Część II. Żywieniowe czynniki ryzyka zespołu metabolicznego. Probl Hig Epidemiol 2011; 92: 747-752.

6. Ventura AK, Worobey J. Early influences on the development of food preferences. Curr Biol 2013; 23: R401-R408.

7. Wojciechowska J. Rodzinne środowisko żywieniowe jako istotny czynnik kształtowania nawyków żywieniowych u dzieci i młodzieży. Piel Pol 2014; 1: 34-40.

8. Skolik A. Smak w analizie sensorycznej. Wyd. Uniwersytetu Ekonomicznego w Poznaniu, Poznań 2011; 9-12.

9. Donaldson LF, Bennett L, Baic S, et al. Taste and weight: Is there a link? Am J Clin Nutr 2009; 90: 800S-803S.

10. Lichtenstein S, Slovic P. The Construction of Preference. Cambridge University Press, New York 2006.

11. Drewnowski A. Taste preferences and food intake. Annu Rev Nutr 1997; 17: 237-253.

12. Rollins, BY, Loken E, Birch LL. Stability and change in snack food likes and dislikes from 5 to 11 years. Appetite 2010; 55: 371-373.

13. Gawęcki J (ed.). Żywienie człowieka. Podstawy nauki o żywieniu. Tom 1. Wydawnictwo Naukowe PWN, Warszawa 2010.

14. Desor JA, Beauchamp GK. Longitudinal changes in sweet preferences in humans. Physiol Behav 1987; 39: 639-641.

15. Beauchamp GK, Moran M. Acceptance of sweet and salty tastes in 2-year-old children. Appetite 1984; 5: 291-305. 
16. Liem DG, Mennella JA. Heightened sour preferences during childhood. Chem Senses 2003; 28: 173-180.

17. Reed DR, Knaapila A. Genetics of taste and smell: poisons and pleasures. Prog Mol Biol Transl Sci 2010; 94: 213-240.

18. Gawęcki J, Baryłko-Pikielna. Zmysły a jakość żywności i żywienia. Wyd. Uniwersytetu Przyrodniczego w Poznaniu, Poznań 2015; 25-27.

19. Tepper BJ. Nutritional implications of genetic taste variation: the role of PROP sensitivity and other taste phenotypes. Annu Rev Nutr 2008; 28: 367-388.

20. Kim UK, Drayna D. Genetics of individual differences in bitter taste perception: Lessons from the PTC gene. Clin Genet 2005; 67: 275-280.

21. Calo C, Padiglia A, Zonza A, et al. Polymorhisms in TAS2R38 and the taste bud trophic factor, gustin gene cooperate in modulating PROP taste phenotype. Physiol. Behav 2011; 104: 1065-1071.

22. Ligaj D. Smak gorzki w kształtowaniu jakości żywności. Wydawnictwo Uniwersytetu Ekonomicznego w Poznaniu, Poznań 2015; 21-24.

23. Nicklaus S. The Role of Dietary Experience in the Development of Eating Behavior during the First Years of Life. Ann Nutr Metab 2017; 70: 241-245.

24. Pepino MY, Mennella JA. Factors contributing to individual differences in sucrose preference. Chem Senses 2005; 30 (Suppl 1): i319-320.

25. Rolland-Cachera MF, Maillot M, Deheeger M, et al. Association of nutrition in early life with body fat and serum leptin at adult age. Int J Obes (Lond) 2013; 37: 1116-1122.

26. Kern DL, McPhee L, Fisher J, et al. The postingestive consequences of fat condition preferences for flavors associated with high dietary fat. Physiol Behav 1993; 54: 71-76.

27. Johnson SL, McPhee L, Birch LL. Conditioned preferences: young children prefer flavors associated with high dietary fat. Physiol Behav 1991; 50: 1245-1251.

28. Schwartz C, Chabanet C, Lange C, et al. The role of taste in food acceptance at the beginning of complementary feeding. Physiol Behav 2011; 104: 646-652.

29. Szajewska H, Socha P, Horvath A, et al. Zasady żywienia zdrowych niemowląt. Zalecenia Polskiego Towarzystwa Gastroenterologii, Hepatologii i Żywienia Dzieci. Standardy Medyczne. Pediatria 2014; 11: 321-328.

30. Paroche MM, Samantha J, Caton SJ, et al. How Infants and Young Children Learn About Food: A Systematic Review. Front Psychol 2017; 8: 1046.

31. Galloway AT, Fiorito LM, Francis LA, et al. "Finish your soup": counterproductive effects of pressuring children to eat on intake and affect. Appetite 2006; 46: 318-323.

32. Wardle J, Carnell S, Cooke L. Parental control over feeding and children's fruit and vegetable intake: how are they related? J Am Diet Assoc 2005; 105: 227-232.

33. Fiese BH, Jones BL. Food and family: A socio-ecological perspective for child development. Adv Child Dev Behav 2012; 42: 307-337.

34. Jarosz M, Wolnicka K, Kłosowska J. Czynniki środowiskowe związane z występowaniem nadwagi i otyłości wśród dzieci i młodzieży. Post Nauk Med 2011; 24: 770-777.

35. Jayasinghe S, Kruger R, Walsh DC, et al. Is sweet taste perception associated with sweet food liking and intake. Nutrients 2017; 9: 750.

36. Cox DN, Hendrie GA, Carty D. Sensitivity, hedonics and preferences for basic tastes and fat amongst adults and children of differing weight status: A comprehensive review. Food Qual Prefer 2016; 48: 359-367.

37. Lanfer A, Knof K, Barba G, et al. Taste preferences in association with dietary habits and weight status in European children: results from the IDEFICS study. Int J Obes (Lond) 2012; 36: 27-34.

38. Bartoshuk LM, Duffy VB, Hayes JE, et al. Psychophysics of sweet and fat perception in obesity: problems, solutions and new perspectives. Philos Trans R Soc Lond B Biol Sci 2006; 361: 1137-1148.
39. Cicerale S, Riddell LJ, Keast RS. The association between perceived sweetness intensity and dietary intake in young adults. J Food Sci 2012; 77: H31-H35.

40. Lim J, Urban L, Green BG. Measures of individual differences in taste and creaminess perception. Chem Senses 2008; 33: 493-501.

41. Gawęcki J. Fizjologiczne uwarunkowania wyboru pokarmu. Rolka bodźców sensorycznych w dostosowaniu wyboru pokarmu do potrzeb organizmu. Żyw Człow Metab 1982; 9: 147-158.

42. Kato Y, Roth R. Relationship between taste sensitivity and eating style in Japanese female university students. Food Nutr Sci 2012; 3: 302-309.

43. Rozin P, Tuorola H. Simultaneous and temporal contextual influences on food acceptance. Food Qual Prefer 1993; 4: 11-20.

44. Sartor F, Donaldson, LF, Markland DA, et al. Taste perception and implicit attitude toward sweet related to body mass index and soft drink supplementation. Appetite 2011; 57: 237-246.

45. Drewnowski A, Kurth CL, Rahaim JE. Taste preferences in human obesity: Environmental and familial factors. Am J Clin Nutr 1991; 54: 635-641.

46. Stewart JE, Keast RS. Recent fat intake modulates fat taste sensitivity in lean and overweight subjects. Int J Obes (Lond) 2012; 36: 834-842.

47. Overberg J, Hummel T, Krude H, et al. Differences in taste sensitivity between obese and non-obese children and adolescents. Arch Dis Child 2012; 97: 1048-1052.

48. Pasquet P, Frelut ML, Simmen B, et al. Taste perception in massively obese and in non-obese adolescents. Int J Pediatr Obes 2007; 2: 242-248.

49. Gawęcki J, Galiński G. Sensoryczne mechanizmy regulacji apetytu. Kosmos 2010; 59: 281-290.

50. Drewnowski A, Kurth CL, Rahaim JE. Taste preferences in human obesity: Environmental and familial factors. Am J Clin Nutr 1991; 54: 635-641.

51. Stewart JE, Keast RS. Recent fat intake modulates fat taste sensitivity in lean and overweight subjects. Int J Obes (Lond) 2012; 36: 834-842.

52. Green BG, Lim J, Osterhoff F, et al. Taste mixture interactions; Suppresion, additivity and the predominance of sweetness. Physiol Behav 2010; 101: 731-737.

53. DiPatrizio NF. Is fat taste ready for primetime? Physiol Behav 2014; 136: $145-154$

54. Baker SS, Baker RD. Early exposure to dietary sugar and salt. Pediatrics 2015; 135: 550-551.

55. Sausenthaler S, Koletzko S, Koletzko B, et al. Effect of hydrolysed formula feeding on taste preferences at 10years. Data from the German infant nutritional intervention program plus study. Clin Nutr 2010; 29: 304-306.

56. Brekke HK, van Odijk J, Ludvigsson J. Predictors and dietary consequences of frequent intake of high-sugar, low-nutrient foods in 1-year-old children participating in the ABIS study. Br J Nutr 2007; 97: 176-181.

57. Fisher JO, Birch LL. Parents' restrictive feeding practices are associated with young girls' negative self-evaluation of eating. J Am Diet Assoc 2000; 100: 1341-1346.

58. Vollmer RL, Bartoshuk LM. Practices and preferences: Exploring the relationships between food-related parenting practices and child food preferences for high fat and/or sugar foods, fruits, and vegetables. Apetite 2017; 113: 134-140. 